\title{
Editor's Introduction
}

On March 29, 1994, the Federal Reserve Bank of St. Louis hosted a symposium on the implications of rapid mutual fund growth for monetary policy. From 1990-93, household holdings of shares in bond and equity mutual funds increased at a record pace. During the same period, the Federal Reserve's primary monetary aggregate, M2, grew much more slowly than suggested by its historical relationships to economic activity and opportunity costs. Does the confluence of these events suggest that M2 has become less useful as an indicator of the stance of monetary policy? Should it be replaced with a new aggregate that includes these mutual funds?

Financial innovation and advances in technology change the structure of financial markets, alter the indicator properties of monetary aggregates, and give rise to pressures for their redefinition. When Regulation Q capped deposit offering rates during the 1970 s, for example, many households learned that money market mutual funds provided an attractive alternative to holding bank and thrift deposits. As a result, money market funds were included in M2 when it was redefined in 1980. During the 1980s, households became increasingly familiar with financial institutions other than banks and thrifts. Mortgage loans were increasingly originated by morigage brokers, auto loans extended by finance companies, and retirement funds held in selfmanaged IRA and Keogh accounts. At the same time, the mutual fund industry benefited from technical progress that reduced the cost of servicing large customer lists and managing portfolios of marketable securities.

Thus, participants on both sides of the financial markets seemed poised to react swiftly during the 1990 s to the combination of a sharp decrease in the overall level of market interest rates and a record widening of maturity-related yield spreads. Available survey and anecdotal evidence, as well as negative statistical correlations in the aggregate data, suggest that households shifted savings away from traditional depository institutions toward bond and equity mutual funds. With offering rates on deposits decreasing, prospective returns on bond and equity funds often appeared to be three- or four-fold greater.

The subsequent slow growth of M2 during a period when many analysts perceived monetary policy as becoming increasingly expansionary led to doubts about its usefulness as a policy indicator. The monetary aggregates were offcially de-emphasized as policy guides in Federal Reserve Board Chairman Greenspan's July 1993 Humphrey-Hawkins Act testimony before Congress. At about the same time, a group of economists at the Board of Governors completed two studies evaluating whether M2 might usefully be replaced by a redefined aggregate that included bond and equity mutual fund shares. These studies, and the five commentaries that appear here, were presented at the St. Louis symposium. Written by economists closely involved in policy analysis, the studies provide a unique perspective on the range of issues that arise whenever it is suggested that a monetary aggregate be redefined.

Before a monetary aggregate may be used, it must be measured. In the first article, Sean Collins and Cheryl Edwards discuss the measurement of a monetary aggregate $\mathrm{M} 2+$ that includes both $\mathrm{M} 2$ and shares in bond and equity mutual funds. They first describe how interest in redefining an aggregate arises when its growth differs from that suggested by its historical behavior. Although necessary, such deviant behavior may not be sufficient unless there also has been significant innovation or technical progress in financial markets since the previous redefinition of the aggregates. The latter imparts an a priori reasonableness to suspicions that the array of money substitutes available to households and firms has expanded, or that the transaction costs of substituting among various alternatives has decreased.

The current M2 monetary aggregate is designed to measure household and firm holdings of liquid assets that are either available for spending now 
or will become so in the near future. Retaining this focus in a new monetary aggregate that includes bond and equity mutual funds requires separating institutional holdings of mutual fund shares from those held by firms and households, as Collins and Edwards discuss in the latter half of their article. Further, data on several items that are not included in the new aggregate, such as the M2-type assets owned by the bond and equity funds and the amount of mutual fund shares held by households as illiquid retirement balances, are also required. These amounts are subtracted from the new aggregate.

Collins and Edwards discuss several unique problems that arise while building $\mathrm{M} 2$ + that have no direct parallel in the current monetary aggregates. One is the inclusion of assets denominated in foreign currencies. All components of the current official monetary aggregates (M1, M2, M3 and L) are denominated in U.S. dollars. Mutual funds that invest in foreign currency-denominated assets, however, have been among the most rapidly growing type of funds in recent years. Second, current $\mathrm{M} 2$ includes only assets that are capital-certain or, in other words, only assets whose value does not vary with the level of market interest rates. Capital gains and losses are a significant factor in changes in the value of bond and equity funds, and present a thorny problem for both the construction and interpretation of the M2+ aggregate.

In the policy arena, monetary aggregates may be valuable as either targets or indicators, with requirements for the former generally more stringent than for the latter. In both cases, the aggregate must have a reliable empirical relationship to future economic activity. In addition, to be useful as a policy target, the demand for the aggregate must be a stable function of a relatively small number of variables and the Federal Reserve must be able to control the aggregate's growth. In the second article, Athanasios Orphanides, Brian Reid and David Small judge the $\mathrm{M} 2+$ monetary aggregate relative to each of these criteria.

Modeling the demand for a monetary aggregate requires identifying its close substitutes and, in turn, the opportunity cost of holding the components of the aggregate rather than alternative assets. The inclusion of capital-uncertain assets in $\mathrm{M} 2+$ complicates calculation of its own rate of return and identification of an appropriate opportunity cost. The authors conclude that the nonbank public's holdings of bond and equity fund shares seem to respond to both the spread between the return on the mutual fund and the Treasury bill yield, and the change during the previous period in the overall level of market rates or equity prices.

In the latter part of their article, Orphanides, Reid and Small examine the stability of the demand for $\mathrm{M} 2+$ and its value as a leading indicator for nominal GDP. Working within the linear error-correction framework developed by Board staff in previous money demand studies, they find a reasonably good overall fit to the data. Yet, the estimated semi-elasticities of M2+ demand with respect to market yields and various measures of its opportunity cost appear highly sensitive to the form in which these variables enter the regression. Perhaps more disappointing, however, is their conclusion that $\mathrm{M} 2+$ has not been a generally better indicator than M2 of movements in nominal GDP growth during the 1990s.

In their commentary, William Barnett and Ge Zhou interpret the definition of $\mathrm{M} 2+$ as a dynamic index number problem. When the financial assets in an economy can be partitioned into two non-overlapping groups - those that provide monetary (transaction) services and those that do not-the economy's money stock is correctly measured by summing the quantities of the assets in the former group. It is the essence of financial innovation, however, to blur the distinction between these groups and allow assets in the latter category to provide monetary as well as non-monetary services. The authors show, however, that sequentially redefining a broad monetary aggregate may cause the aggregate to move further away from, rather than closer to, the economy's true money stock. They laud the authors of the symposium's two major papers for grappling with the difficult issue of including capital-uncertain assets in a monetary aggregate.

Jacob Dreyer doubts, however, that a new $\mathrm{M} 2+$ monetary aggregate would be useful to policymakers. The necessity of estimating expected holding period yields likely precludes obtaining useful estimates of a demand equation for the aggregate. He also argues that turnover rates suggest that bond and equity mutual funds lack the necessary degree of "moneyness" for them to reasonably be included in a monetary aggregate along with the current components of M2. Although acknowledging that the transaction 
costs of buying and selling bond and equity funds have fallen sharply, he regards this change as creating only the illusion, rather than the substance, of moneyness.

In his commentary, John Duca attributes the slower-than-anticipated growth of M2 during the 1990s to a combination of changes in banking regulation and the pattern of market interest rates. Duca notes that significant shifts in financial intermediation also occurred in the 1970s and 1980 s when government regulation interacted with large movements in market interest rates. Nevertheless, he concludes that the unprecedented steep slope of the yield curve during a period when offering rates on bank and thrift deposits fell to their lowest levels in decades likely was the primary motivation for households to substitute holdings of bond and equity funds for M2-type assets during the 1990s. This substitution does not, by itself, call for a redefinition of $M 2$, however,

Josh Feinman suggests that the dramatic shrinkage of the federal subsidy to the depository sector since 1990 seems to have played the larger role in depressing $\mathrm{M} 2$ growth. He cites higher deposit insurance premiums, new capital standards and stricter supervision as examples. These changes reduced the incentive for depositories to pursue their traditional lending and deposit-taking activities, resulting in an increasing proportion of intermediation being conducted through market instruments such as corporate equity and commercial paper, popular investments of bond and equity mutual funds. He doubts that $\mathrm{M} 2+$ could ever be useful as a policy target or indicator. In his view, the inverse correlation between movements in market interest rates and the value of the capital-uncertain assets included in M2+ likely precludes formulating any policy feedback rules based on $\mathrm{M} 2+$.

George Pennacchi suggests that households' increased holdings of mutual fund shares might be interpreted as a reaction to the narrower rate spreads between liquid and time deposits at banks during the 1990s. Reductions in transaction costs and improvements in computer technology have increased the liquidity of bond and equity mutual funds, making them more competitive with liquid deposits in such an environment. He suggests that the lower turnover rates of bond and equity fund shares should not be taken as evidence that households have not responded to, and do not value, the increased liquidity of the funds.

Moreover, although the funds are subject to liquidity (interest rate) risk, economic theory suggests that the expected holding period yields of these mutual funds should not differ systematically, on balance, from other market returns.

Finally, I want to recognize the economic analysts in the Research Department of the Federal Reserve Bank of St. Louis who provided invaluable help in reviewing references and data for the symposium papers: Heidi L. Beyer, Heather Deaton, Kelly M. Morris and Richard D. Taylor.

Richard G. Anderson

St. Louis, Missouri

November 1, 1994 